\title{
Bacteria Recovered from Cultured Gilt-Head Seabream (Sparus aurata) and their Antimicrobial Susceptibilities
}

\author{
Ozgur Canak*, Tulay Akayli \\ Istanbul University, Faculty of Aquatic Sciences, Department of Fish Diseases, İstanbul, Turkey
}

Please cite this article as: Canak O, Akayli T. Bacteria Recovered from Cultured Gilt-Head Seabream (Sparus aurata) and their Antimicrobial Susceptibilities. Eur J Biol 2018; 77(1): 11-7.

\section{ABSTRACT}

Objective: Gilt-head seabream (Sparus aurata) is an important species for Turkish aquaculture and bacterial diseases are one of the limiting factors for the production of this species. The aim of this study is the identification of the bacterial disease agents in cultured gilt-head seabream in Turkey and the determination of their antibacterial susceptibilities.

Materials and Methods: In this study, 27 diseased gilt-head seabream samples between 3-130 g, showing various clinical symptoms, were examined bacteriologically. Bacterial isolates recovered from moribund fish samples were identified by using standard bacteriological methods and API 20E rapid identification strips. Antibiotic susceptibility tests of 10 different substances against these isolates were determined by using Kirby-Bauer disc diffusion method.

Results: Vibrio anguillarum, V. scophthalmi, V. logei, V. harveyi, Pseudomonas anguilliseptica, P. stutzeri, Staphylococcus sp. and Micrococcus luteus isolates were isolated from diseased fish samples as pure and mixed infection. It was detected that API $20 E$ may give erroneous results for fish pathogenic bacteria since they are not included in the database of the kit. Generally, enrofloxacin, florphenicol and oxytetracycline were found to be the most effective antibiotics against bacterial isolates.

Conclusion: This study is the first report for V. scophthalmi, V. logei, V. harveyi, P. stutzeri and M. luteus infections of gilt-head seabream in Turkey.

Keywords: Gilt-head seabream, fish diseases, vibriosis, antibiogram susceptibility

\section{INTRODUCTION}

Gilt-head seabream (Sparus aurata) is one of the most common species cultured in the Mediterranean basin and Turkey is among the leading producer countries with a production of 58.254 tons in $2016(1,2)$. Despite the fact that Turkey has suitable environmental conditions and a sufficient number of large-scale hatcheries for the production of this fish species, bacterial diseases are the main limiting factor of production. A great majority of the infectious diseases of gilthead seabream are caused by Gram-negative bacteria, especially Vibrio representatives $(3,4)$.

Previously, various Gram-negative bacteria such as Vibrio anguillarum (also known as Listonella anguillarum), V. alginolyticus, V. ordalii, Aeromonas hydrophila, Photobacterium damselae subsp. piscicida, Ph. damselae subsp. damselae, Pseudomonas fluorescens and Flavobacterium $s p$. were isolated from infected gilthead seabream cultured in Turkey (5-13). Gram- positive bacteria also caused diseases in this species in Turkey and Staphylococcus epidermidis and S. hominis infections were reported $(14,15)$.

Antibacterial substances have been used in the therapy of bacterial fish diseases for more than 60 years. As the production amount and the number of cultured fish species has increased, the frequency and diversity of the fish diseases has also shown an increase and a greater amount of antibiotics were used in this period (16). This increase in the use of antibacterial substances has brought about a number of problems. Various factors such as the incorrect use or dose of antibacterial substances causes the development of resistance in bacteria. Furthermore, the residue of antibacterial substances in cultured fish is a threat for human health. Hence, the use of some antibacterial substances in aquaculture, such as chloramphenicol, have been banned or limited $(16,17)$. 
The aim of this study is the identification of the bacterial disease agents in cultured gilt-head seabream in Turkey and the determination of their antibacterial susceptibilities.

\section{MATERIALS AND METHODS}

In this study, 27 cultured diseased gilt-head seabream specimens between 3-130 g showing some clinical symptoms of bacterial diseases supplied from 5 different fish farms (will be mentioned as Farm No. 1, 2, 3, 4 and 5 in the rest of the article) located in the Aegean Sea coasts of Turkey were examined bacteriologically between April 2009 and July 2010 (17, 18). After anesthesia with 2-phenoxyethanol, bacteriological inoculations from the liver, kidney and spleen of the fish samples were made onto TSA (Tryptic Soy Agar) containing 1.5\% NaCl, TCBS and Marine Agar. Inoculated media were incubated at $22^{\circ} \mathrm{C}$ for 72 hours. Bacterial isolate growths from moribund fish samples were identified based on their biochemical profiles by using standard laboratory methods (17-19).

API 20E rapid identification strips (Biomerieux, France) were used as an additional method. Since it is not discriminative for Gram-positive bacteria, this kit was not used for these isolates and they were identified by using the results of the standard laboratory methods only (17). API 20E test strips were used according to the instructions of the manufacturer. Briefly, fresh cultures of bacteria were suspended in sterile distilled water containing $0.85 \% \mathrm{NaCl}$ and well emulsified. Bacterial suspension was added into the wells of the test strip and incubated at $24{ }^{\circ} \mathrm{C}$ for $24-48$ hours.

Antibacterial susceptibilities of these isolates against 10 different substances were determined by using the Kirby-Bauer disc diffusion method, which was replicated three times and evaluated according to the CLSI standards (20). Briefly, fresh cultures of bacterial isolates were suspended in sterile phosphate buffered saline (PBS) and diluted to a turbidity equivalent to the McFarland tube No. 0.5 standard solution. The bacterial suspension $(0.1 \mathrm{ml})$ was spread onto MuellerHinton agar and antibiotic disks were placed (21). Petri dishes were incubated at $22{ }^{\circ} \mathrm{C}$ for $18-24$ hours and the sensitivity zones were measured with a ruler and their arithmetic mean was calculated.

\section{RESULTS}

During the field sampling studies, slow swimming behavior near the surface of the seawater and loss of appetite was detected in all moribund fish samples. In the $20 \mathrm{~g}$ fish samples examined in farm no 1, hemorrhages at the fin bases and anus, erosion in the lower jaw and anemia in the internal organs were observed (Figures $1 \mathrm{a}$ and $1 \mathrm{~b}$ ). In the $80 \mathrm{~g}$ fish samples examined in farm no 2, pale skin color, loss of scales, ulcers and lesions on the skin, hemorrhages at the base of the fins, anemia in the gills and internal organs and in some samples the accumulation of a translucent fluid were observed (Figures $1 \mathrm{c}$ and $1 \mathrm{~d}$ ). In the $10 \mathrm{~g}$ fish samples examined in farm no 3, loss of scales, erosion in the lower jaw, fin base hemorrhages, shallow skin lesions and ane- mia in the internal organs were observed (Figures 1e and 1f). In 3-6 $\mathrm{g}$ fish samples examined in farm no 4, distended abdomen and pale skin color, distended liver with petechial hemorrhages, splenomegaly and liquefaction in the kidney were observed (Figures $1 \mathrm{~g}$ and $1 \mathrm{~h}$ ). In $130 \mathrm{~g}$ fish samples examined in farm no 5 , distended abdomen, pale skin color, loss of scales, hemorrhages on the internal organs, splenomegaly and accumulation of a bloody fluid in the intestines and peritoneal cavity were observed (Figures $1 \mathrm{i}$ and $1 \mathrm{j}$ ).

A total of 15 bacterial isolates were recovered from the visceral organs of moribund fish samples. Depending on their morphological and biochemical properties that are shown in Table 1, these isolates were identified as $V$. anguillarum $(n=6), V$. scophthalmi $(n=3), V$. logei $(n=1), V$. harveyi $(n=1), P$. anguilliseptica $(n=1), P$. stutzeri $(n=1)$, Staphylococcus sp. $(n=1)$ and Micrococcus luteus $(n=1)$.

As a result of bacterial identification studies carried out after the bacterial examination of the fish samples, V. anguillarum was recovered as a pure infection in fish samples obtained from fish farm no 1. Mixed infections of $V$. anguillarum with V. scophthalmi in one fish and $V$. harveyi in another fish sample were detected in fish farm no 2. In fish farm no 3, mixed infections of $V$. anguillarum and $V$. scophthalmi in the first fish sample; $V$ anguillarum and $V$. logei in the second fish sample and $V$. anguillarum and $P$. stutzeri in the third fish sample were detected. Moreover, a pure $V$. anguillarum infection in one fish sample, mixed infections of $V$. anguillarum and Staphylococcus sp. in the second fish sample and $V$. anguillarum and $M$. luteus in the third fish sample were detected in fish farm no 4 . A pure infection of $P$. anguilliseptica was detected in fish farm no 5 .

As a result of the antimicrobial susceptibility tests, generally, enrofloxacin, oxytetracycline and ciprofloxacin were found to be the most effective antibiotics against all bacterial isolates. Florphenicol and sulphametaxozole-trimetoprim were found to be the most effective antibiotics against Vibrio spp. isolates. Despite being recovered from different fish farms, isolates of the same species gave similar results in the antimicrobial susceptibility testing. Most of the isolates showed a complete resistance to ampicillin and streptomycin. Antimicrobial susceptibility test results of these isolates are shown in Table 2.

\section{DISCUSSION}

Gilt-head seabream are commonly cultured in the Mediterranean basin and Turkey is one of leading countries in the production of this species $(1,2)$. Bacterial diseases are one of the most important limiting factors in fish production (17). Identification of the pathogens involved in the disease conditions of the gilt-head seabream and taking proper precautions for the treatment of disease is the key to success in the culture of this species. This study was carried out for the detection of bacterial pathogens affecting gilt-head seabream cultured in the Aegean Sea coasts of Turkey and determination of their antimicrobial susceptibilities. 


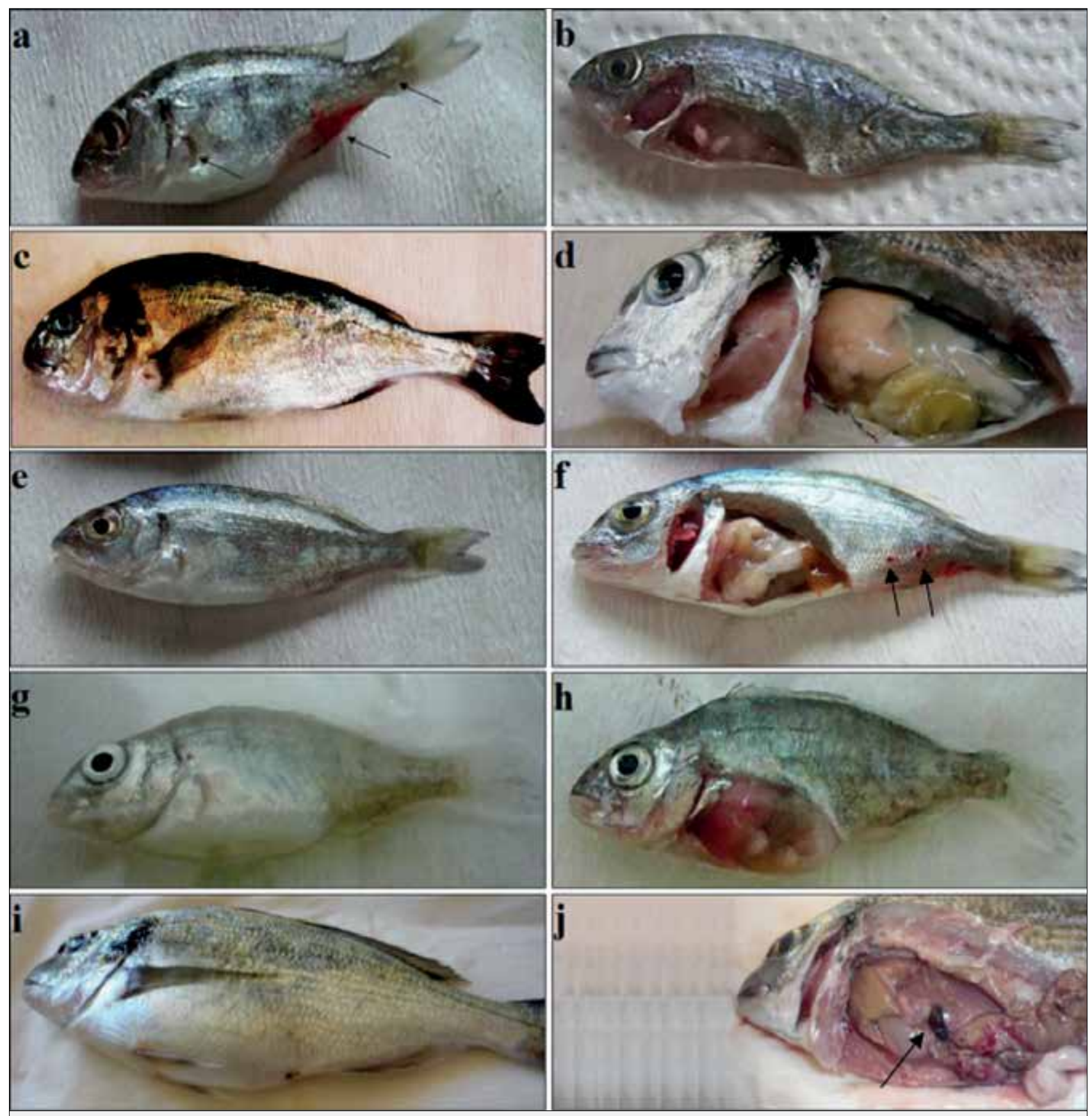

Figure 1. General clinical external and internal symptoms observed in fish samples a \& b: Farm no 1 (ulcers on the body are indicated by arrows), c \& d: Farm no 2 (loss of scales and anemia in the internal organs), e \& f: Farm no 3 (hemorrhages and ulcers on the body [indicated by arrows], anemia in the liver), g \& h: Farm no 4 (distended abdomen, erosion of the caudal fin and distended liver), i \& j: Farm no 5 (distended abdomen, splenomegaly [indicated by arrows] and fluid accumulation in the intestines).

In the field studies, general clinical symptoms such as pale skin color, loss of scales, hemorrhages and ulcers on the body surface and anemia in the internal organs were observed and showed similarities with previous reports for each particular bacterial fish pathogen $(7,17,18)$.

Previously, various researchers conducted long-term disease monitoring studies on gilthead seabream and they all reported that they have recovered Gram-negative bacteria in a great majority (more than 90\%), particularly the Vibrio species $(70 \%)(3,4,12)$. Similarly, in this study, it was determined that the members of the genus Vibrio are the main pathogens of this fish species and some other bacteria are involved in cases of mixed infections.

Vibriosis is a common bacterial fish disease worldwide that is caused by various Vibrio species and $V$. anguillarum is among 
Table 1. Phenotypic and biochemical properties of bacterial isolates

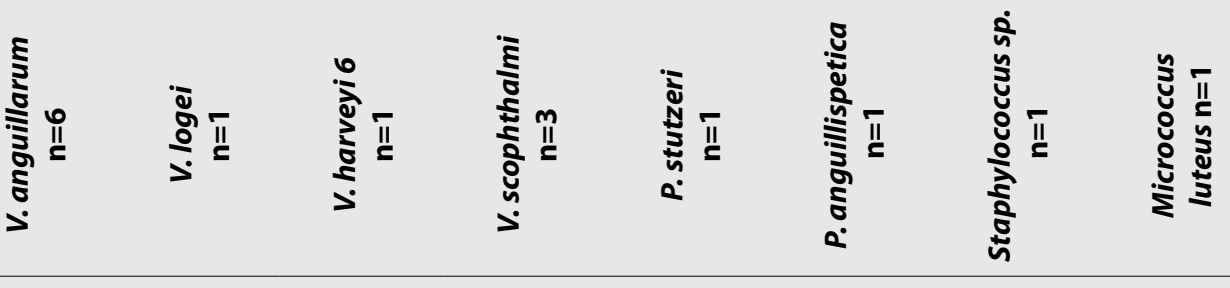

\begin{tabular}{|c|c|c|c|c|c|c|c|c|}
\hline Gram & - & - & - & - & - & - & + & + \\
\hline Morphology & B & $\mathrm{B}$ & $\mathrm{P}$ & B & $\mathrm{B}$ & B & GLC & $\mathrm{T}$ \\
\hline Motility & + & + & + & + & + & + & - & - \\
\hline $\mathrm{O} / \mathrm{F}$ & $\mathrm{F}$ & $\mathrm{F}$ & $\mathrm{F}$ & $\mathrm{F}$ & $\mathrm{O}$ & $\mathrm{O}$ & $\mathrm{F}$ & $\mathrm{O}$ \\
\hline Oxidase & + & + & + & + & + & + & - & - \\
\hline Catalase & + & + & + & + & + & + & + & + \\
\hline O/129 & $\mathrm{S}$ & $\mathrm{S}$ & $\mathrm{S}$ & $\mathrm{S}$ & $\mathrm{R}$ & $\mathrm{R}$ & $\mathrm{R}$ & $\mathrm{R}$ \\
\hline TCBS & $\mathrm{Y}$ & G & $\mathrm{Y}$ & $\mathrm{Y}$ & - & - & - & - \\
\hline VAM & $\mathrm{Y}$ & $\mathrm{Y}$ & - & - & - & - & - & - \\
\hline Arginine & + & - & - & + & - & - & - & - \\
\hline Lysine & - & + & + & - & - & - & - & - \\
\hline Ornithin & - & + & + & - & - & - & + & + \\
\hline Indole & + & + & + & - & - & - & - & - \\
\hline Methyl Red & - & - & - & - & - & - & - & - \\
\hline VP & + & - & - & - & - & + & + & - \\
\hline ß-galactosidase & + & + & - & - & - & - & - & - \\
\hline Gelatinase & + & - & - & - & + & - & - & - \\
\hline Amilase & + & - & - & - & - & - & - & - \\
\hline Aesculine & - & + & W & + & - & - & - & - \\
\hline Haemolysis & $\beta$ & $\beta$ & $\beta$ & Y & $a$ & $\beta$ & $a$ & $a$ \\
\hline Urease & - & - & - & - & - & - & + & - \\
\hline Citrate & - & + & - & - & + & - & - & - \\
\hline Nitrate reduction & + & + & - & + & + & + & + & - \\
\hline $\mathrm{H} 2 \mathrm{~S}$ & - & - & - & - & - & - & - & + \\
\hline \multicolumn{9}{|c|}{ Acid production from } \\
\hline Fructose & + & + & - & + & - & + & - & - \\
\hline Arabinose & + & - & - & - & - & - & - & - \\
\hline Mannitol & + & - & + & + & - & - & - & - \\
\hline Mannose & - & + & - & + & - & - & - & - \\
\hline Xylose & - & + & + & + & - & - & - & - \\
\hline Lactose & - & + & + & + & - & - & - & - \\
\hline \multicolumn{9}{|l|}{ Growth at } \\
\hline $4^{\circ} \mathrm{C}$ & W & - & - & - & W & + & - & - \\
\hline $37^{\circ} \mathrm{C}$ & + & - & + & + & + & - & + & + \\
\hline $40^{\circ} \mathrm{C}$ & W & - & + & - & - & - & + & + \\
\hline $0 \% \mathrm{NaCl}$ & - & - & - & - & - & + & + & + \\
\hline $3 \% \mathrm{NaCl}$ & + & + & + & + & + & + & + & + \\
\hline $5 \% \mathrm{NaCl}$ & + & + & + & + & + & + & + & + \\
\hline $8 \% \mathrm{NaCl}$ & - & - & - & - & - & W & - & W \\
\hline \multirow[t]{3}{*}{ API 20E Profile(s) } & 3247526 & 5764105 & 4356525 & 2000024 & 0200004 & 2200004 & $\mathrm{~N} / \mathrm{A}$ & $\mathrm{N} / \mathrm{A}$ \\
\hline & 3047127 & & & 2000124 & & & & \\
\hline & 3267126 & & & & & & & \\
\hline
\end{tabular}

+: Positive reaction, -: Negative reaction, B: Bacilli, P: Pleomorphic, GLC: Grape-like clusters, T: Tetrad, O: Oxidative, F: Fermentative, S: Sensitive, R: Resistant, Y: yellow, G: green, W: Weak reaction, VAM: Vibrio anguillarum medium, a: Alpha-hemolysis, $\beta$ : Beta-hemolysis, Y: Gamma-hemolysis 
Table 2. Antibiotic susceptibilities of bacterial isolates recovered from moribund gilt-head seabream samples (mean zone diameter in $\mathrm{cm}$ )

\begin{tabular}{|c|c|c|c|c|c|c|c|c|}
\hline & 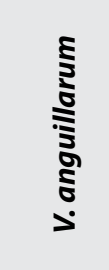 & 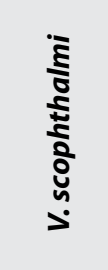 & 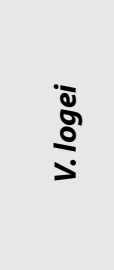 & 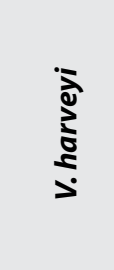 & 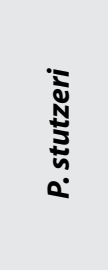 & 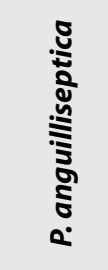 & 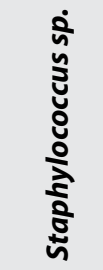 & $\begin{array}{l}\stackrel{n}{\Xi} \\
\stackrel{\Xi}{\Xi} \\
\dot{\Sigma}\end{array}$ \\
\hline Erythromycin $(15 \mu \mathrm{g})$ & $\mathrm{R}(1.4)$ & $\mathrm{R}(1.5)$ & $\mathrm{R}(1.1)$ & I (1.9) & $\mathrm{R}(1.3)$ & $\mathrm{R}(0)$ & $\mathrm{I}(1.7)$ & S (4) \\
\hline Enrofloxacin $(5 \mu \mathrm{g})$ & $\mathrm{I}(2.5)$ & $\mathrm{S}(3)$ & $I(2)$ & $\mathrm{I}(2)$ & $\mathrm{S}(3.3)$ & $\mathrm{I}(2.2)$ & $\mathrm{S}(2.7)$ & $\mathrm{I}(1.6)$ \\
\hline Oxytetracycline $(30 \mu \mathrm{g})$ & $\mathrm{I}(2)$ & $\mathrm{S}(2.9)$ & $I(2)$ & $I(1.8)$ & $\mathrm{I}(2.4)$ & $\mathrm{R}(1.5)$ & $\mathrm{I}(2.5)$ & $S(2.8)$ \\
\hline Ampicillin $(10 \mu \mathrm{g})$ & $\mathrm{R}(0)$ & $\mathrm{I}(2.2)$ & $\mathrm{R}(0)$ & $\mathrm{R}(0)$ & $\mathrm{I}(2)$ & $\mathrm{R}(0)$ & $\mathrm{R}(1.2)$ & $S(4.1)$ \\
\hline Kanamycin $(30 \mu \mathrm{g})$ & $\mathrm{R}(1.6)$ & $\mathrm{I}(2)$ & $\mathrm{R}(1.3)$ & $\mathrm{R}(1.5)$ & $I(2)$ & $I(1.7)$ & $\mathrm{R}(1.5)$ & $\mathrm{I}(2.3)$ \\
\hline Ciprofloxacin $(5 \mu \mathrm{g})$ & $\mathrm{I}(2.5)$ & $\mathrm{S}(2.9)$ & $\mathrm{I}(1.8)$ & $I(1.9)$ & $\mathrm{S}(3.1)$ & $I(2.3)$ & $\mathrm{I}(2)$ & $\mathrm{R}(1.4)$ \\
\hline Flumequine $(30 \mu \mathrm{g})$ & $\mathrm{I}(2.4)$ & $\mathrm{S}(3.2)$ & $\mathrm{S}(2.6)$ & $I(2.2)$ & $\mathrm{S}(3.7)$ & $I(1.6)$ & $I(2.2)$ & $\mathrm{R}(0)$ \\
\hline Florphenicol $(30 \mu \mathrm{g})$ & $S(3.6)$ & $\mathrm{S}(3.1)$ & $\mathrm{S}(2.8)$ & $\mathrm{S}(3)$ & $\mathrm{I}(2.3)$ & $\mathrm{R}(0)$ & $\mathrm{R}(0)$ & S (4) \\
\hline Streptomycin $(10 \mu \mathrm{g})$ & $\mathrm{R}(0)$ & $\mathrm{R}(0)$ & $\mathrm{R}(0.9)$ & $\mathrm{R}(1.1)$ & $\mathrm{R}(1.3)$ & $\mathrm{R}(0)$ & $\mathrm{R}(0)$ & $S(2.6)$ \\
\hline $\begin{array}{l}\text { Trimethoprim } \\
\text { sulfamethoxazole }(25 \mu \mathrm{g})\end{array}$ & $\mathrm{S}(2.8)$ & S (3) & S (3) & I (2) & $\mathrm{S}(3.3)$ & $\mathrm{R}(0)$ & $S(3.2)$ & $\mathrm{R}(0)$ \\
\hline
\end{tabular}

the oldest of known fish pathogens and is reported to affect more than 48 aquatic species world-wide (17-21). It has been reported to be involved in the diseases of various cultured marine fish species such as gilt-head seabream, Atlantic salmon, European sea bass, red porgy and also rainbow trout cultured in marine and freshwater environment in Turkey (5,6,22-32).

V. harveyi was previously recovered from moribund gilthead seabream in Spain by Balebona et al. (3) and Zorrilla et al. (4). This bacterium was also recovered from moribund European seabass in Turkey by Korun and Akayli (33) and Korun and Timur (25). V. scophthalmi was previously recovered from the tank water in turbot culture (34) and turbot intestinal flora (35), but it was reported as a non-pathogenic species by Cerda-Cuellar et al. (36). V. logei was previously recovered from moribund cultured Atlantic salmon in Iceland (37). As stated above among the Vibrio species isolated from gilt-head seabream in this study, $V$. anguillarum was previously reported from this fish species in Turkey, but V. harveyi, V. scophthalmi and V. logei, were recovered for the first time in mixed infections of gilt-head seabream cultured in Turkey.

P. anguilliseptica, which causes winter disease, was previously recovered from moribund cultured gilthead seabream in France and this bacterium is rarely recovered from gilt-head seabream in Turkey $(38,39)$. It was also previously reported from cultured European sea bass in Turkey (11). In this study, this bacterium was recovered from a chronically infected fish sample in summer, where a great majority of the batch was lost due to this infection in winter.

P. stutzeri, a bacterium that is found in freshwater, marine and soil environments and in wastewater $(40,41)$ was reported among the most abundant bacteria in Iskenderun Bay, Turkey by Matyar et al. (42). This bacterium also caused disease in rainbow trout in freshwater environments (43). In this study, this organism was recovered from the moribund cultured gilthead seabream in Turkey for the first time.

As previously reported in long-term disease monitoring studies of gilt-head seabream $(3,4,12)$, Gram-positive bacteria were also recovered in this study too. One isolate could only be identified at the genus level as Staphylococcus sp. Previously, Kubilay and Ulukoy (14) reported a Staphylococcus epidermidis infection and Korun et al. (15) reported a S. hominis infection in gilthead seabream cultured in Turkey. Another Gram-positive isolate was identified as Micrococcus luteus. This organism was reported to be a pathogen of gilt-head seabream in Spain (3), and in this study, it was recovered from moribund gilt-head seabream cultured in Turkey for the first time.

API 20E bacterial identification kits were first developed for the rapid identification of medically important bacteria and later they were used in the field of fish disease (44), but in many cases, erroneous identification results have been achieved. Since $V$. anguillarum is not included in the API database, Santos et al. (45) reported that 35 of their $53 \mathrm{~V}$. anguillarum strains were misidentified as Aeromonas hydrophila and, furthermore, they have faced similar problems with other important fish pathogens such as A. sobria, A. caviea and Y. ruckeri. Austin et al. (46) recorded 117 different API 20E profiles with their $260 \mathrm{~V}$. anguillarum isolates from various parts of the world. Altun et al. (30) and Balta and Balta (32) reported that their V. anguillarum isolates were misidentified as $V$. vulnificus by this kit.

Similarly, in this study 3 different API 20E profiles (3247526, 3047127 and 3267126) were recorded with $V$. anguillarum isolates including a very similar profile as the dominant profile ob- 
tained by Austin et al. (46); 3247527. However, in the API 20E database, our isolates were all misidentified as A. hydrophila. A very similar profile (3207526), with only one difference in the indole test result, was also reported by Balta (26) with $V$. anguillarum strains isolated from moribund European sea bass cultured in the Black Sea region of Turkey. When the previously reported API 20E profiles and the results of this study were evaluated, it was detected that generally citrate, sorbitol and indole test results can be variable in this kit for V. anguillarum (46). This variability in the API 20E test results of $V$. anguillarum strains isolated from various regions of Turkey was also previously reported $(24,26)$.

Previously, Soffientino et al. (47) reported an API 20E profile of 4356525 with a V. carchariae (which is another name for $V$. harveyi) strain isolated from cultured summer flounder in the USA. The same API 20E profile was recorded in this study with the $V$. harveyi isolates and it was misidentified in the API database as $V$. alginolyticus. Also, other fish pathogenic bacteria, Pseudomonas stutzeri and $P$. anguilliseptica isolated from moribund gilt-head seabream in this study were both misidentified as Pseudomonas fluorescens/putida with this kit. Hence, when using biochemical tests, more reliable results to identify Vibrios and other fish pathogenic bacteria can be obtained with systemic bacterial identification books $(17,48)$ or specially designed identification keys $(19)$. Besides biochemical methods, for a more precise identification of the fish pathogenic bacteria, the use of species-specific molecular or serologic methods would be useful $(15,17,18,24,26,30)$.

Despite the common use of antibiotics in disease treatment, these substances are only a small part of a comprehensive management plan and should not be relied upon exclusively to solve all health problems in aquaculture (16). Proper culturing methods should be applied and prophylactic precautions such as the use of probiotics or vaccination should be taken for the prevention of disease outbreaks (17).

Generally, enrofloxacin, oxytetracycline and ciprofloxacin were found to be the most effective antibiotics against all bacterial isolates. In particular, florphenicol and sulphametaxozole-trimetoprim were found to be the most effective antibiotics against 11 Vibrio spp. isolates.

Florphenicol, flumequin, furanase, nutrafurazon, oxolinic acid, oxytetracycline and sulphamerazin were reported to be used successfully in the treatment of fish vibriosis (17). Also, Korun (6) reported that oxytetracycline treatment for 7 days has been successful against the $V$. anguillarum infection in gilthead seabream. But in this study, it was determined that $V$. anguillarum isolates showed a slight resistance to oxytetracyline and more successful results were achieved against this bacterium with other substances in in vitro tests. Altun et al. (30) also reported a resistance to oxytetracycline in $V$. anguillarum. Balta and Balta (32) applied a treatment with florphenicol during a $V$. anguillarum infection in rainbow trout and achieved good results. Similarly, in this study, florphenicol was found to be effective on V. anguillarum isolates. Also, Balta (26) reported that all $V$. anguillarum strains isolated from cultured European seabass showed ampicillin-resistance and florphenicol was found to be effective against this bacterium. Similar results were obtained in this study too. In contrast, Altun et al. (30) reported that some of their $V$. anguillarum strains recovered from rainbow trout developed a resistance to many antibiotics including florphenicol and sulphametaxozol.

Ciprofloxacin and enrofloxacin were found to be effective against Pseudomonads and moreover, it was detected that $P$. anguilliseptica is resistant to 6 of the 10 antimicrobials tested. The results showed that, enrofloxacin, oxytetracycline and sulphametaxozole-trimetoprim were the most effective antibiotics against Staphylococcus sp. while erythromycin, ampicillin and florphenicol were effective against Micrococcus luteus.

\section{CONCLUSION}

In conclusion, as the main purpose of aquaculture is to produce fish for human consumption, it is recommended that less dangerous methods such as probiotics, immunostimulants and vaccines should be used for health management and prophylaxis in aquaculture instead of antimicrobials. If it is obligatory, in each epizootic observed in aquaculture, the required tests should be performed on the bacterial isolates and the most suitable antibacterial substance should be used while bearing in mind the banned substances list. Hence, healthier food for human consumption will be produced and bacterial resistance will be prevented.

Acknowledgement: This work was supported by Istanbul University Scientific Research Projects Fund (Project No. 5087).

Conflict of Interest: The authors have no conflict of interest to declare.

\section{REFERENCES}

1. Fao.org. (2017). FAO Fisheries \& Aquaculture Sparus aurata. [online] Available at: http://www.fao.org/fishery/culturedspecies/ Sparus_aurata/en [Accessed 14 Oct. 2017].

2. Tuik.gov.tr. (2017). Turkish Statistical Institute [online] Available at: http:// www.tuik.gov.tr/PreTablo.do?alt_id=1005 [Accessed 14 Oct. 2017].

3. Balebona M, Zorrilla I, Moriñigo M, Borrego J. Survey of bacterial pathologies affecting farmed gilt-head sea bream (Sparus aurata L.) in southwestern Spain from 1990 to 1996 . Aquaculture 1998; 166(1-2): 19-35. [CrossRef]

4. Zorrilla I, Chabrillón M, Arijo S, Dı'az-Rosales P, Martı'nez-Manzanares $E$, Balebona $M$, Moriñigo $M$. Bacteria recovered from diseased cultured gilthead sea bream (Sparus aurata L.) in southwestern Spain. Aquaculture 2003; 218(1-4): 11-20. [CrossRef]

5. Candan A. Vibrio anguillarum infection in Sparus aurata L. 1758. Turk Mikrobiyol Cem Derg 1993; 23: 25-7.

6. Korun J. A study on Listonella anguillarum infection occurred in cultured gilt-head sea bream (Sparus aurata L.). Ege JFAS 2006; 23(1/2): 259-263.

7. Akayli T. Identification of Vibriosis in cultured gilthead seabream (Sparus aurata, L 1758) by using ELISA and bacteriological methods. Istanbul University, Institute of Science, Ph.D. Thesis. 2001.

8. Tanrikul TT. Outbreaks of Vibrio alginolyticus in gilthead sea bream in Turkey. Ind Vet J 2006; 83: 599-601. 
9. Candan A. Vibrio ordalii infection in Sparus aurata L. 1758. Turkish J Aqua Sci 1993; 1-2: 91-4.

10. Timur G, Timur M, Akayli T, Camlibel UR. Oodinium and Vibrio co-infections in cultured gilthead seabream (Sparus aurata). Turkish J Aqua Sci 2004; 17: 9-18.

11. Turk N. Cipura (Sparus aurata) ve levrek (Dicentrarchus labrax) yavrularından bakteri izolasyonu ve antibiyotiklere duyarlılıklarının belirlenmesi. Bornova Vet Kont Araşt Enst Derg 2002; 27:7-14.

12. Akayli T, Ozesen Colak, S, Yardimci E. Bacterial infections in Sparus aurata cultured in Turkey. Ind Vet J 2009; 86(11): 1294-5.

13. Cagirgan $\mathrm{H}$. The first isolation of Pasteurella piscicida from cultured sea bream (Sparus aurata) in Turkey. Hay Arast Derg 1993; 3(2): 17-19.

14. Kubilay A, Ulukoy G. First isolation of Staphylococcus epidermidis from cultured gilthead sea bream (Sparus aurata) in Turkey. Bull Eur Ass Fish Pathol 2004; 24(3): 137-43.

15. Korun J, Yilmaz M., Gokoglu, M. and Bulguroglu, S. First record of Staphylococcus hominis from the cultured gilthead sea bream (Sparus aurata) in Turkey. In the proceedings of "17th European Association of Fish Pathologists Conference"; 7-11 Sept 2015; Las Palmas-Spain; 368.

16. Hernández Serrano P. Responsible use of antibiotics in aquaculture. Rome, Italy; Food and Agriculture Organization of the United Nations; 2005.

17. Austin B, Austin D. Bacterial fish pathogens, diseases of farmed and wild fish. 6th edition; Dordrecht-Netherlands; Springer Publishing; 2016. [CrossRef]

18. Roberts R. Fish pathology. 4th edition; Hoboken, N.J; Wiley-Blackwell; 2012. [CrossRef]

19. Noguerola I, Blanch A. Identification of Vibrio spp. with a set of dichotomous keys. Appl Microbiol 2008; 105(1): 175-85. [CrossRef]

20. Wikler M. Performance standards for antimicrobial susceptibility testing. Wayne, PA; Clinical and Laboratory Standards Insitute; 2006.

21. Koneman, EW. Color atlas and textbook of diagnostic microbiology 3rd edition. JB Lippincott; 1992.

22. Candan A. Türkiye'de üretilen Atlantik salmon (Salmo salar L.)'nda tespit edilen ilk vibriosis olgusu. Turk Mikrobiyol Cem Derg 2000; 30: 107-8.

23. Timur G, Timur M, Akayli T, Korun J, Thompson KD. First observation of Rickettsia-like organisms in cultured sea bass (Dicentrarchus labrax) in Turkey. Bull Eur Ass Fish Pathol 2005; 25(5):196-202.

24. Demircan D, Candan A. Identification of Vibrio anguillarum by PCR (rpoN gene) associated with vibriosis in marine fish in Turkey. Turk J Vet Anim Sci 2006; 30: 305-310.

25. Korun J, Timur G. Marine vibriosis associated with diseased seabass (Dicentrarchus labrax) in Turkey. J FishSci.com 2008; 2(1): 66-76.

26. Balta F. Phenotypic, serotypic and genetic characterization and antimicrobial susceptibility determination of Vibrio anguillarum, isolated from cultured sea bass (Dicentrarchus labrax L., 1758) in the southeast Black Sea, Turkey. Fresen Environ Bull 2016; 25(10): 4393-400.

27. Korun J, Gokoglu M. Listonella anguillarum isolated from hatchery cultured red porgy Pagrus pagrus in Turkey. J Anim Vet Adv 2007; 6(6): 823-7.

28. Timur G, Korun J. First outbreak of vibriosis in farmed rainbow trout (Oncorhynchus mykiss) in Turkey. Turkish J Aqua Sci 2004; 18(18): 1-9.

29. Tanrikul TT. Vibriosis as an epizootic disease of rainbow trout (Onchorhynchus mykiss) in Turkey. Pak J Biol Sci 2007; 10(10): 1733-7. [CrossRef]

30. Altun S, Buyukekiz AG, Duman M, Onuk EE, Ciftci A, Mustak HK. Gökkuşağı alabalıklarında L. anguillarum'un fenotipik, genotipik özelliklerinin ve antimikrobiyal duyarlılıklarının belirlenmesi. In: Proceedings of "3. Ulusal Alabalık Sempozyumu"; 24-26 May 2013; Kastamonu, Turkey; 33.
31. Akayli T, Aydin S, Canak O. Kültür gökkuşağı alabalıkarında (O. mykiss W. 1792) V. anguillarum'un teşhisi. In: Proceedings of "5. Doğu Anadolu Bölgesi Su Ürünleri Sempozyumu"; 31 May - 2 June 2014; Elazı̆̆, Turkey; 402-405.

32. Balta F, Dengiz Balta Z. Doğu Karadeniz'de yetiştiriciliği yapılan gökkuşağı alabalıkları (Oncorhynchus mykiss)'ndan izole edilen Vibrio anguillarum suşlarının serotiplendirilmesi, genetik karakterizasyonu ve antimikrobiyal duyarlıı̆ı̆ın belirlenmesi. Ankara Üniv Vet Fak Derg 2017; 64(4): 321-8. [CrossRef]

33. Korun J, Akayli T. Kültür levrek (Dicentrarchus labrax) balıklarında parazitik bir isopod: Ceratothoa oestroides ve sekonder bakteriyel infeksiyonlar olgusu. Acta Vet Eurasia 2004; 30(2): 123-32.

34. Farto R, Montes M, Pérez M, Nieto T, Larsen J, Pedersen K. Characterization by numerical taxonomy and ribotyping of Vibrio splendidus biovar I and Vibrio scophthalmi strains associated with turbot cultures. Appl Microbiol 1999; 86(5): 796-804. [CrossRef]

35. Cerda-Cuellar M, Blanch A. Determination of Vibrio scophthalmi and its phenotypic diversity in turbot larvae. Appl Environ Microbiol 2004; 6(3):209-17.

36. Cerda-Cuellar M, Rossello-Mora R, Lalucat J, Jofre J, Blanch, A. Vibrio scophthalmi sp. nov., a new species from turbot (Scophthalmus maximus). Int J Syst Bacteriol 1997; 47(1): 58-61. [CrossRef]

37. Benediktsdottir E, Helgason S, Sigurjonsdottir H. Vibrio spp. isolated from salmonids with shallow skin lesions and reared at low temperature J Fish Dis 1998; 21: 19-28. [CrossRef]

38. Domenech A, Fernandez-Garayzabal JF, Lawson P, Garcia JA, Cutuli MT, Blanco M, et al. Winter disease outbreak in sea-bream (Sparus aurata) associated with Pseudomonas anguilliseptica infection. Aquaculture 1997; 156(3-4): 317-26. [CrossRef]

39. Cagirgan $\mathrm{H}$. The use of veterinary drugs and vaccines in Turkey. Options Mediterraneennes 2009; 86: 29-34.

40. Rosselo R, Garcia-Valdes E, Lalucat J, Ursing J. Genotypic and phenotypic diversity of Pseudomonas stutzeri. System Appl Microbiol 1991; 14(2): 150-7. [CrossRef]

41. Sikorski J, Mohle M, Wackernagel W. Identification of complex composition, strong strain diversity and directional selection in local Pseudomonas stutzeri populations from marine sediment and soils. Appl Environ Microbiol 2002; 4(8): 465-76.

42. Matyar F, Akkan T, Ucak Y, Eraslan B. Aeromonas and Pseudomonas: antibiotic and heavy metal resistance species from İskenderun bay, Turkey (northeast Mediterranean Sea). Environ Monit Assess 2010; 167(1-4): 309-20. [CrossRef]

43. Akinbowale $\mathrm{OL}$, Peng $\mathrm{H}$, Grant $\mathrm{P}$, Barton MD. Antibiotic and heavy metal resistance in motile aeromonads and pseudomonads from rainbow trout (Oncorhynchus mykiss) farms in Australia. Int J Antimicrob Agents 2007; 30: 177-82. [CrossRef]

44. Topic Popovic N, Coz-Rakovac R, Strunjak-Perovic I. Commercial phenotypic tests (API 20E) in diagnosis of fish bacteria: a review. Veterinarni Medicina 2007; 52: 49-53. [CrossRef]

45. Santos Y, Romalde JL, Bandin I, Magarinos B, Nunez S, Barja JL, Toranzo $A E$. Usefulness of the API-20E system for the identification of bacterial fish pathogens. Aquaculture 1993; 116(2-3): 111-20. [CrossRef]

46. Austin B, Alsina DA, Austin DA, Blanch AR, Grimont F, et al. Identification and typing of Vibrio anguillarum: a comparison of different methods. System Appl Microbiol 1995; 18: 285-302. [CrossRef]

47. Soffientino B, Gwaltney T, Nelson DR, Specker JL, Mauel M, Gómez-Chiarri M. Infectious necrotizing enteritis and mortality caused by Vibrio carchariae in summer flounder Paralichthys dentatus during intensive culture. Dis Aquat Organ 1999; 38: 201-10. [CrossRef]

48. Garrity GM, Brenner DJ, Krieg NR, Staley JT, editors. Bergey's manual of systematic bacteriology, 2nd edition Vol:2 The Proteobacteria Part C The Alpha-, Beta-, Delta- and Epsilon Proteobacteria. Springer, 2006. 